\title{
TERAPI TERTAWA DAN PERUBAHAN TEKANAN DARAH PADA MAHASISWA DI UNIVERSITAS ADVENT INDONESIA
}

\section{THERAPY AND CHANGE OF BLOOD PRESSURE IN STUDENTS IN THE UNIVERSITY OF ADVENT INDONESIA}

\author{
Tawarina Surbakti ${ }^{1}$, Gilny Aileen Joan², Denny Ricky ${ }^{3}$ \\ Fakultas IImu Keperawatan Universitas Advent Indonesia \\ Email: karorina@rocketmail.com
}

\begin{abstract}
ABSTRAK
Penelitian ini dilatarbelakangi hasil penelitian Ramdhani (2013) yang menunjukan adanya perubahan penurunan tekanan darah yaitu setelah dilakukan terapi tertawa selama dua minggu sebanyak enam kali pemberian. Maka peneliti merasa perlu dilakukan uji ulang pemberian terapi tertawa pada tekanan darah normal dengan satu kali pemberian. Tujuan penelitian untuk menganalisis perbedaan tekanan darah sebelum dan sesudah pemberian terapi tertawa pada mahasiswa di Universitas Advent Indonesia. Desain penelitian yang digunakan dalam penelitian ini adalah penelitian eksperimen yang menggunakan One Group Pre-Test and Post-Test Design dengan melibatkan satu kelompok subjek. Intervensi dalam penelitian yang dilakukan ini adalah pemberian terapi tertawa selama 20 menit. Subjek penelitian ini berjumlah 30 orang mahasiswi di Universitas Advent Indonesia. Pengambilan sampel dilakukan dengan teknik purposive sampling.

Hasil penelitian ini menunjukan bahwa nilai rata-rata tekanan darah pada mahasiswi di Universitas Advent Indonesia sebelum pemberian terapi tertawa yaitu dengan nilai tekanan darah sistolik adalah $115.6 \mathrm{mmHg}$ dan nilai tekanan darah diastolik 75.0 $\mathrm{mmHg}$. Nilai rata-rata tekanan darah sistolik sesudah pemberian terapi tertawa adalah $110.8 \mathrm{mmHg}$ dan tekanan darah diastolik $73.8 \mathrm{mmHg}$. Nilai tekanan darah sebelum dan sesudah pemberian terapi tertawa mempunyai nilai yang signifikan pada nilai ujit pada tekanan sistolik. Tekanan diastolik tidak terjadi perubahan yang signifikan.
\end{abstract}

Kata kunci: Tekanan darah normal, Terapi tertawa

\begin{abstract}
This research is based on the writing of Ramdhani (2013) showing that there is a change in blood pressure after given six times laughter therapy for two weeks. Researchers find it necessary to repeat the laugh therapy on person with normal blood pressure with one provision. The purpose of this research is to identify changes in blood pressure before and after given laugh therapy. The research design used in this study is One Group Pre-Test and Post-Test Design experimental research that uses. Intervention conducted in this research is laughing therapy for 20 minutes. Subjects of this research were 30 students of Adventist University of Indonesia. That were by purposive sampling technique.

The results of this research showed that the average value of blood pressure in students of Universitas Advent Indonesia before given laugh therapy with a systolic blood pressure value of $115.6 \mathrm{~mm} \mathrm{Hg}$ and diastolic blood pressure value of 75.0 $\mathrm{mmHg}$. The average value of systolic blood pressure after the administration of laughter therapy was $110.8 \mathrm{mmHg}$ and a diastolic blood pressure value of $73.8 \mathrm{mmHg}$. Systolic blood pressure values before and after administration of laughter therapy has a significant change but not with the diastolic.
\end{abstract}

Keywords: Normal blood pressure value, Laugh therapy
JURNAL

SKOLASTIK KEPERAWATAN

Vol. 2, No.2

Juli - Desember 2016

ISSN: $2443-0935$

E-ISSN: 2443 - 1699 


\section{PENDAHULUAN}

Ridwan (2009) menuliskan bahwa tekanan darah adalah kekuatan yang diperlukan agar darah dapat mengalir di dalam pembuluh darah dan beredar mencapai semua jaringan manusia. Ronny (2008) menuliskan bahwa tekanan darah adalah tekanan yang dihasilkan oleh darah terhadap pembuluh darah. Tekanan darah dipengaruhi volume darah dan elastisitas pembuluh darah. Price \& Potter (2006) menuliskan bahwa bahwa faktor-faktor yang mempengaruhi tekanan darah yaitu jenis kelamin, usia, stres, dan medikasi.

Berk et al, (1996) menuliskan bahwa tertawa sama dengan efek latihan fisik yang membantu meningkatkan suasana hati, menurunkan hormon stres, meningkatkan aktivitas kekebaan tubuh, dan menurunkan tekanan darah. Hasan \& Hasan (2009) mengatakan terapi tertawa adalah salah satu cara untuk mencapai kondisi rileks. Tertawa merupakan pemicu peningkatan sistem saraf parasimpatetik dan juga penurunan kerja sistem saraf simpatetik. Peningkatan kerja sistem saraf simpatik berfungsi untuk memberikan tenaga bagi gerakan pada tubuh, namun hal ini juga diikuti oleh penurunan sistem saraf simpatetik yang salah satunya disebabkan oleh adanya perubahan kondisi otot yang lebih rileks, dan pengurangan pemecahan terhadap nitric oxide yang membawa pada pelebaran pembuluh darah, sehingga rata-rata tertawa menyebabkan aliran darah meningkat sebesar 20\%, sementara stres menyebabkan penurunan aliran darah sekitar 30\%.

Kataria (2004) menuliskan bahwa terapi tertawa berguna menyembuhkan penyakit atau setidaknya menjaga tubuh dalam kondisi yang baik. Meskipun tidak banyak orang yang mendengar tentang hal itu, terapi tawa telah ada selama bertahun-tahun. Tawa digunakan sebagai terapi untuk menyembuhkan penyakit dan menjaga tubuh tetap sehat. Penelitian sebelumnya menyatakan bahwa terapi tertawa memiliki pengaruh yang signifikan terhadap fisiologis \& psikologis manusia. Terbukti melalui penelitian Ramdhani (2013) yang menyatakan bahwa terapi tawa membantu penderita hipertensi menurunkan tekanan darah hipertensi derajat satu dengan sistolik 142 dan diastolik $76 \mathrm{mmHg}$, pada saat posttest terjadi penurunan rerata tekanan darah menjadi 118/71 mmHg. Sedangkan Christina, et al (2015) menyatakan bahwa terapi tertawa memberikan pengaruh dalam penurunan stres psikologis lansia di Panti Werdha Kota Manado.

Hasil penelitian yang dilakukan oleh Ramdhani (2013) terjadi perubahan tekanan darah yaitu dari 142/76 menjadi 118/71 $\mathrm{mmHg}$ setelah dilakukan terapi tertawa selama dua minggu sebanyak enam kali pemberian. Maka peneliti merasa perlu dilakukan uji ulang pemberian terapi tertawa pada tekanan darah normal dengan satu kali pertemuan dengan judul "TERAPI TERTAWA DAN PERUBAHAN TEKANAN DARAH PADA MAHASISWA DI UNIVERSITAS ADVENT INDONESIA"

\section{BAHAN DAN METODE}

Alat dan bahan yang digunakan dalam penelitian ini adalah alat ukur tekanan darah sphigmomanometer dan stetoskop, jam tangan, lembar observasi dan alat tulis, kuesioner HARS (Hamilton Anxiety Rating Scale).

Metode yang digunakan dalam penelitian ini adalah eksperimen dengan one group pre test and post test. Subjek penelitian yang digunakan berjumlah 30 orang mahasiswa dewasa yang memiliki tekanan darah normal. Pemilahan subjek penelitian menggunakan metode purposive sampling (Riduwan, 2007).

Pengukuran tekanan darah dilakukan sebanyak satu kali yaitu sebelum pemberian terapi tertawa dan setelah pemberian terapi tertawa terhadap tekanan darah subjek penelitian. Penelitian ini menggunakan terapi tertawa yang ditulis oleh Dr. Madan Kataria: Laugh For No Reason (Terapi Tawa). 
HASIL

Hasil yang dianalisa dalam penelitian ini adalah tekanan darah subjek sebelum dan sesudah pemberian terapi tertawa.

Tabel 1 melampirkan hasil analisa tekanan darah sebelum terapi tertawa.

\begin{tabular}{|c|c|c|c|c|}
\hline \multirow[t]{2}{*}{ No. } & \multicolumn{2}{|c|}{$\begin{array}{c}\text { Tekanan Darah } \\
\text { Sistolik }\end{array}$} & \multicolumn{2}{|c|}{$\begin{array}{c}\text { Tekanan } \\
\text { Darah } \\
\text { Diastolik }\end{array}$} \\
\hline & Pre & Post & Pre & Post \\
\hline 1 & 120.0 & 110.0 & 80.0 & 75.0 \\
\hline 2 & 120.0 & 115.0 & 70.0 & 70.0 \\
\hline 3 & 120.0 & 115.0 & 80.0 & 80.0 \\
\hline 4 & 120.0 & 120.0 & 80.0 & 80.0 \\
\hline 5 & 120.0 & 115.0 & 80.0 & 80.0 \\
\hline 6 & 110.0 & 110.0 & 70.0 & 70.0 \\
\hline 7 & 110.0 & 110.0 & 70.0 & 80.0 \\
\hline 8 & 120.0 & 115.0 & 80.0 & 70.0 \\
\hline 9 & 110.0 & 100.0 & 70.0 & 70.0 \\
\hline 10 & 110.0 & 120.0 & 70.0 & 70.0 \\
\hline 11 & 110.0 & 110.0 & 70.0 & 70.0 \\
\hline 12 & 120.0 & 120.0 & 80.0 & 70.0 \\
\hline 13 & 110.0 & 100.0 & 70.0 & 70.0 \\
\hline 14 & 110.0 & 110.0 & 70.0 & 70.0 \\
\hline 15 & 120.0 & 110.0 & 80.0 & 70.0 \\
\hline 16 & 110.0 & 100.0 & 70.0 & 70.0 \\
\hline 17 & 120.0 & 115.0 & 80.0 & 80.0 \\
\hline 18 & 120.0 & 120.0 & 80.0 & 80.0 \\
\hline 19 & 120.0 & 120.0 & 70.0 & 70.0 \\
\hline 20 & 110.0 & 100.0 & 70.0 & 70.0 \\
\hline 21 & 110.0 & 110.0 & 70.0 & 70.0 \\
\hline 22 & 110.0 & 110.0 & 70.0 & 70.0 \\
\hline 23 & 120.0 & 110.0 & 80.0 & 70.0 \\
\hline 24 & 110.0 & 110.0 & 70.0 & 70.0 \\
\hline 25 & 110.0 & 110.0 & 70.0 & 80.0 \\
\hline 26 & 120.0 & 110.0 & 80.0 & 80.0 \\
\hline 27 & 120.0 & 110.0 & 80.0 & 80.0 \\
\hline 28 & 120.0 & 110.0 & 80.0 & 80.0 \\
\hline 29 & 120.0 & 110.0 & 80.0 & 70.0 \\
\hline 30 & 120.0 & 110.0 & 80.0 & 80.0 \\
\hline
\end{tabular}

Berdasarkan hasil pengolahan data SPSS versi 16 terdapat perbedaan yang signifikan pada tekanan darah sistolik. Tekanan darah diastolik tidak terdapat perbedaan yang signifikan.

\section{PEMBAHASAN}

Analisis diatas menunjukan bahwa ada penurunan tekanan darah sesudah pemberian terapi tertawa. Hal tersebut memperlihatkan bahwa penelitian yang dilakukan dalam satu kali pemberian terapi tertawa selama 20 menit memberikan pengaruh yang signifikan terhadap penurunan tekanan darah sistolik.

Tekanan darah dari suatu tempat peredaran darah ditentukan oleh tiga macam faktor yaitu: jumlah darah yang ada di dalam peredaran yang dapat membesarkan pembuluh darah; aktivitas memompa jantung, yaitu mendorong darah sepanjang pembuluh darah; tahanan perifer terhadap aliran darah. Selanjutnya faktor-faktor yang mempengaruhi tahanan perifer yaitu viskositas darah, tahanan pembuluh darah (jenis pembuluh darah, panjang, dan diameter), serta turbulensi (kecepatan aliran darah, penyempitan pembuluh darah, dan keutuhan jaringan) (Suprayogi, 2007).

Pembuluh darah memberikan reaksi atas peningkatan aliran darah melalui kontraksi dan peningkatan perifer. Ketika jantung berdetak atau berkontraksi, darah akan terdorong melalui arteri ke seluruh tubuh. Tekanan darah diastolik adalah jumlah tekanan darah atau angka bawah yang menunjukkan tekanan dalam arteri saat jantung beristirahat (di antara ketukan/detak) (Udjianti, 2010).

Pada jantung normal, peningkatan peregangan serat-serat otot jantung menyebabkan filamen-filamen miosin dan aktin berkaitan secara lebih tepat dan seratserat otot berkontraksi lebih kuat. Hal ini akan terjadi pada saat olah raga dan sewaktu jantung terisi oleh darah. Namun, apabila volume diastolik-akhir terlalu meningkat atau apabila jantung tidak mampu berespon terhadap peregangan seratseratnya dengan meningkatkan kontaktilitas, maka filamen miosin dan aktin terpisah dan 
kontraksi jantung menurun. Gagal jantung adalah keadaan saat ventrikel secara progresif terisi lebih banyak darah daripada yang dapat dipompa keluar dan kemampuan jantung ampak menurun pada kurva panajng-tegangan (Muttaqin, 2009).

Terapi tertawa dapat digunakan sebagai alternatif untuk penurunan tekanan darah. Hasil penelitian sejalan dengan penelitian yang dilakukan oleh Ramdhani (2013) yang menyatakan bahwa terapi tawa membantu penderita hipertensi menurunkan tekanan darah hipertensi derajat satu dengan sistolik 142 dan diastolik $76 \mathrm{mmHg}$, pada saat posttest terjadi penurunan rerata tekanan darah menjadi 118/71 $\mathrm{mmHg}$.

Hasan \& Hasan (2009) mengatakan bahwa terapi tertawa adalah salah satu cara untuk mencapai kondisi rileks. Tertawa merupakan paduan dari peningkatan sistem saraf simpatetik dan juga penurunan kerja sistem saraf simpatetik. Berk et al, (1996) menuliskan bahwa tertawa sama dengan efek latihan fisik yang membantu meningkatkan suasana hati, menurunkan hormon stres, meningkatkan aktivitas kekebalan tubuh, menurunkan tekanan darah.

\section{KESIMPULAN}

Sistolik memiliki perbedaan yang signifikan dan cukup data untuk menolak hipotesis sedangkan diastolik kurang cukup untuk menolak hipotesis pada pemberian terapi tertawa pada mahasiswa di Universitas Advent Indonesia

\section{DAFTAR PUSTAKA}

Christina, et al. 2015. Pengaruh Terapi Tertawa Terhadap Stres Psikologis Pada Lansia Di Panti Werdha Kota Manado. eJournal keperawatan (eKep) Volume 3. Nomor 2. Hal 7.

Hasan, H., \& Hasan, T.F. 2009. Laugh yourself into healthier person : a cross cultural analysis of the effect of verying level of laughter on health.
International Journal of Medical Sciences, 6(4), 200-211.

Kataria, M. (2004). Laugh For No Reason

(Terapi Tawa). Jakarta: PT Gramedia

Pustaka Utama.

Muttaqin, A. (2009). Pengantar Asuhan Keperawatan Klien dengan Gangguan

Sistem Kardiovaskular. Jakarta:

Salemba Medika

Ramdhani, N. 2013. Terapi tawa untuk menurunkan Stres pada penderita

Hipertensi. Jurnal Psikologi Volume 40, No. $1: 15-27$.

Riduwan. (2007). Rumus dan Data Dalam Analisis Statistika. Bandung: Alfabeta.

Ronny, et al. (2008). Fisiologi Kardiovaskular: Berbasis masalah keperawatan.

Buku Kedokteran : EGC.

Potter \& Perry. 2008. Buku ajar fundamental keperawatan. Jakarta: Buku

Kedokteran EGC

Udjianti, W. J. (2010). Keperawatan

Kardiovaskuler. Jakarta: Salemba Medika. 